\title{
Sex ratios of leatherback turtles: hatchery translocation decreases metabolic heating and female bias
}

\author{
Annette E. Sieg ${ }^{1, *}$, Christopher A. Binckley ${ }^{2}$, Bryan P. Wallace $^{3,4}$, \\ Pilar Santidrián Tomillo ${ }^{5}$, Richard D. Reina ${ }^{6}$, Frank V. Paladino ${ }^{7}$, James R. Spotila ${ }^{5}$ \\ ${ }^{1}$ Department of Natural Sciences, University of Michigan-Dearborn, 4901 Evergreen Road, \\ Dearborn, Michigan 48128-2406, USA \\ ${ }^{2}$ Department of Biology, Arcadia University, 450 S. Easton Rd., Glenside, Pennsylvania 19038, USA \\ ${ }^{3}$ Global Marine Division, Conservation International, 2011 Crystal Drive, Suite 500, Arlington, Virginia 22203-3709, USA \\ ${ }^{4}$ Division of Marine Science and Conservation, 135 Duke Marine Lab Road, Beaufort, North Carolina 28516-8648, USA \\ ${ }^{5}$ Department of Biology, Drexel University, 3141 Chestnut Street, Philadelphia, Pennsylvania 19104-2816, USA \\ ${ }^{6}$ School of Biological Sciences, Monash University, Victoria 3800, Australia \\ ${ }^{7}$ Department of Biology, Indiana-Purdue University, 2101 E. Coliseum Blvd., Ft. Wayne, Indiana 46805-1499, USA
}

\begin{abstract}
Many sea turtle nesting colonies are in decline worldwide, and a common conservation practice maximizes hatchling production by translocating eggs from threatened nests to protective beach hatcheries. Typically, translocated eggs are 'doomed', or at risk of death due to tidal inundation, predation, or poaching. Sea turtles exhibit temperature-dependent sex determination. We determined how primary sex ratios, estimated from incubation temperatures, were affected by egg clutch translocation to a beach hatchery. We monitored incubation temperatures of eastern Pacific leatherback turtles Dermochelys coriacea in hatchery and in situ clutches at Playa Grande, Costa Rica, throughout each nesting season from 1998 to 2007. In situ clutches were estimated to be $90 \%$ female, whereas hatchery clutches ( $9 \%$ of clutches) were estimated to be $64 \%$ female. Taking into account differences in hatching success of in situ and hatchery nests, the overall sex ratio was $83 \%$ female. The Playa Grande hatchery abiotic environment (sand temperatures, water inputs) was similar to that in situ. However, metabolic heating was significantly reduced in hatchery clutches. The most likely explanation is that temperatures in hatchery clutches were cooler (less female-biased) due to decreases in the number of metabolizing embryos since hatchling success was lower in hatchery clutches than in situ clutches. Alteration of both primary sex ratios and hatching success is the tradeoff for reducing the risk of death to egg clutches by translocation to a hatchery. This tradeoff is not unique to Playa Grande leatherback turtles, and it is a strong indication that hatchery translocation should be used cautiously.
\end{abstract}

KEY WORDS: Dermochelys coriacea - Doomed-egg translocation $\cdot$ Hatchlings $\cdot$ Male production · Temperature-dependent sex determination

Resale or republication not permitted without written consent of the publisher

\section{INTRODUCTION}

Many reptiles exhibit temperature-dependent sex determination (TSD) where incubation temperatures experienced by developing embryos determine their sex (Bull 1980). For endangered oviparous species with TSD, understanding natural variation in offspring sex ratios is critical to conservation efforts that aim to increase the production of hatchlings through managed egg incubation (Morreale et al. 1982). Reptilian taxa with TSD, and typically limited post-ovipositional parental care, naturally influence offspring 
sex ratios via nonrandom nest site selection (reviewed by Wilson 1998). There are a number of well-known environmental factors that affect egg incubation temperatures, and therefore hatchling sex ratios. These include vegetational shading of nests (Janzen 1994, Carrasco et al. 2000), nest substrate characteristics (Hays et al. 2001), egg position within a nest (Standora \& Spotila 1985), and nest depth (Wilson 1998). For reptiles that oviposit large clutches of eggs, such as sea turtles, the number of metabolizing embryos in the nest also affects incubation temperatures and hatchling sex ratios (Broderick et al. 2001, Wallace et al. 2004).

Sea turtles are generally Endangered or Critically Endangered on a global scale, according to the IUCN Red List of Threatened Species (Hilton-Taylor 2000), and people on many sea turtle nesting beaches have established doomed-egg translocation programs to reduce mortality in clutches that are 'doomed' due to predation, poaching, beach erosion and/or tidal inundation (Pfaller et al. 2009). Clutches of eggs are relocated either to artificial incubation chambers, other sections of the nesting beach, or to beach hatcheries (Morreale et al. 1982). As the incubation microenvironment experienced by developing embryos can vary between natural and artificial nests, egg relocation could alter primary sex ratios and other aspects of embryonic development (Mrosovsky 2006, 2008, Pike 2008). A population's primary sex ratio is a key parameter in population viability analysis (reviewed by Ewen et al. 2001) and it is crucial that it be monitored when egg clutches are moved to artificial nests as part of a conservation effort (Morreale et al. 1982, Chan and Liew 1995).

One of the most important nesting colonies of the critically endangered eastern Pacific leatherback turtle Dermochelys coriacea is at Playa Grande, Costa Rica (Santidrián Tomillo et al. 2007), and this population, along with beach sand and nest incubation temperatures, have been extensively monitored since 1993 (Steyermark et al. 1996, Binckley et al. 1998, Reina et al. 2002, Wallace et al. 2004). Playa Grande also has a beach hatchery above the high tide line which receives around $9 \%$ of clutches annually. Beach relocation of some doomed egg clutches up above the high tide line is also employed on Playa Grande, but incubation temperatures of these nests have not been systematically monitored. We took advantage of the long-term Playa Grande dataset and estimated primary sex ratios produced from the beach (in situ) and the hatchery over 9 nesting seasons from 1998 to 2007 using direct measurements of nest temperature during incubation. Sea turtle hatchling sex cannot be directly determined without sacrificing the animal (gonadal histology, reviewed by Broderick et al. 2000), so instead we used a standard indirect estimation method based on the relationship between temperature and sex ratio determined in the laboratory to calculate hatchling sex ratios for this population (Binckley et al. 1998, estimation methods reviewed by Mrosovsky et al. 2009).

We hypothesized that sex ratios of hatchlings produced from the hatchery were similar to those produced from natural nests because of the extensive efforts of field workers to mimic natural nesting conditions (reviewed by Wallace et al. 2004) and the similar sand characteristics and lack of shade in both sites. We assessed the relative influences on incubation temperatures of sand temperature and metabolic heating. These results will better inform both the conservation efforts on the ground at Playa Grande and future demographic modeling of population size for this already critically endangered species.

\section{MATERIALS AND METHODS}

Playa Grande $(3.6 \mathrm{~km})$ is located on the Northern Pacific coast of Costa Rica, and has distinct wet (May to November) and dry (December to April) seasons. The leatherback turtle nesting season at Playa Grande runs from October through February with an approximately Gaussian distribution (Reina et al. 2002).

\section{Monitoring incubation temperatures}

We collected egg clutches from doomed natural oviposition locations at or below the high tide line and translocated the clutches to the beach hatchery on Playa Grande where eggs were reburied mimicking natural deposition (Wallace et al. 2004). We monitored incubation temperatures in 408 translocated ('hatchery') and 776 natural clutches ('in situ'; Eckert \& Eckert 1990).

We put a copper constantan thermocouple $\left( \pm 0.05^{\circ} \mathrm{C}\right)$ into the center of the egg mass of every third clutch in the hatchery. Readings were taken with a BAT 12 thermocouple meter (Physitemp) every other day throughout incubation between 15:00 and 17:00 h. Temperatures were similarly monitored in in situ clutch locations, although a few months in certain years were missed due to logistical constraints (e.g. January 1998 and 1999). We also monitored daily sand temperatures at nest depth 
(75 cm depth) in the hatchery and on the beach with thermocouples placed centrally at each location (i.e. 1 in each location). Metabolic heating is the difference, due to metabolizing embryos, between the sand temperature and the egg clutch incubation temperature (reviewed by Broderick et al. 2001). We specifically focused on metabolic heating during the temperature-sensitive period, or middle third of incubation in sea turtles (see next section 'Estimating sex ratios'), as this is an important component of sex determination and is often considered to be static in studies estimating sex ratios from sand temperatures (e.g. Hays et al. 2003).

\section{Estimating sex ratios}

Sea turtle gonadal differentiation is determined by the majority exposure temperature during the middle third of incubation (Bull 1980, Standora \& Spotila 1985). Based on an average total incubation period of $60 \mathrm{~d}$, we calculated the mean middle-third temperature for each monitored clutch from incubation day 20 to 40 . We estimated sex ratios based on the relationship between incubation temperature and sex ratio determined for Playa Grande leatherback turtles by Binckley et al. (1998) in the laboratory (method reviewed by Mrosovsky et al. 2009). The pivotal temperature (temperature producing 50:50 male to female sex ratio) was $29.4^{\circ} \mathrm{C}$, the transitional range of temperatures (producing a mixture of males and females) was from 29 to $30^{\circ} \mathrm{C}$, eggs incubated above $30^{\circ} \mathrm{C}$ were $100 \%$ female, and below $29^{\circ} \mathrm{C}$ were $100 \%$ male (Binckley et al. 1998). For clutches with mean incubation temperatures within the transitional range, we applied the percentage female observed by Binckley et al. (1998) at the tested incubation temperature that corresponded most closely to that in the clutch. Diel variation within Playa Grande egg clutches is less than $0.5^{\circ} \mathrm{C}$ (Binckley et al. 1998), and we could therefore consider field thermal exposure to be similar to that experienced by eggs incubated in laboratory conditions (van de Merwe et al. 2006). Finally, we assumed negligible seasonal variation in the relationship between incubation temperature and sex ratio for Playa Grande leatherback turtles, although this assumption has yet to be tested in sea turtles (reviewed by Mrosovsky et al. 2009).

Monthly middle-third temperature data from monitored clutches was considered to be representative of all clutches going through their middle third of incubation in a given month. The actual number of in situ and hatchery clutches was known from saturated beach monitoring (Santidrián Tomillo et al. 2007). February and March were beyond the in situ clutch incubation temperature monitoring period in 2 seasons, but the last monitored month (January or February) always exhibited sand and clutch incubation temperatures above the transitional range of temperatures and thus subsequent months could be considered $100 \%$ female. We assumed the potential contribution of clutches going through their middle third of incubation outside of October to March to be negligible (actually $\sim 7 \%$ of annual nests, Reina et al. 2002) because of sand temperatures approaching lower thermal limits on development at the very beginning of the season (25 to $27^{\circ} \mathrm{C}$, Bustard 1972) and hatchling production decreasing to almost zero in nests that hatch in February and beyond (Santidrián Tomillo et al. 2009). We corrected for differences in relative numbers of in situ versus hatchery clutches by weighting the mean sex ratio each month, in each location, by the number of clutches. Sex ratios at $100 \%$ female-producing temperatures in in situ clutches were ground-truthed histologically in 1994 to 1995 (Binckley et al. 1998).

\section{Analyses}

A Box-Cox informed transformation was applied to the mean middle-third temperatures and the calculated metabolic heating values prior to further analysis. A repeated-measures ANOVA (rmANOVA) tested the hypothesis that translocation of egg clutches to the hatchery altered the trajectory of temperature increase during the middle third of incubation. The dependent variable consisted of mean temperatures in each of three $1 \mathrm{wk}$ intervals within the middle third of incubation (early = first third of the middle third of incubation, middle $=$ second third, and late $=$ third third). We tested for significant middle-third temperature differences between hatchery and in situ clutches using the rmANOVA with location as a fixed effect, nesting season as a random effect, and least squares means for comparison of the 2 levels of location. We further tested the hypothesis that differences in sand temperatures in the hatchery versus in the open sand on Playa Grande were responsible for differences in middle-third temperatures using a 2-way analysis of variance (ANOVA). Due to the lack of spatial replication of sand temperature measurement within the hatchery and on the beach, we performed a bootstrapped ANOVA (10000 replicates) on mean $10 \mathrm{~d}$ sand temperatures with location and nesting season as fixed effects. Finally, a multivariate ANOVA 
(MANOVA) tested for overall differences in middlethird incubation temperatures and metabolic heating with location and month as fixed effects. We performed Sidak-corrected multiple comparisons on the estimated marginal means of the levels within month and location and we restricted the MANOVA to just the main effects because this was the minimally adequate model for these data.

Analyses were performed using SPSS 15.0 except for the bootstrapped 2-way ANOVA, which was performed in MATLAB R2008a. An $\alpha=0.05$ was accepted for all tests performed.

\section{RESULTS}

Estimated sex ratios in the hatchery and in in situ egg clutches were strongly female biased in all nesting seasons except 1999 to 2000 (Fig. 1). Estimated in situ sex ratios were female biased $(89.8 \%)$, but hatchery clutches were substantially less biased $(64.5 \%)$. Ranges of monthly middle-third temperatures were $1.3^{\circ} \mathrm{C}( \pm 0.2$ overall) in in situ clutches versus $0.9^{\circ} \mathrm{C}( \pm 0.1)$ in hatchery clutches. Monthly numbers of hatchery and in situ clutches varied, with a median $9 \%$ of clutches translocated to the hatchery. Weighting each monthly estimated sex ratio by the relative number of clutches in each location (hatchery versus in situ) yielded an overall estimated sex ratio of $83.2 \%$ female.

There was a significant effect of clutch location on incubation temperature during the middle third of development (rmANOVA, $F_{1,8}=10.52, \mathrm{p}=0.012$ ).

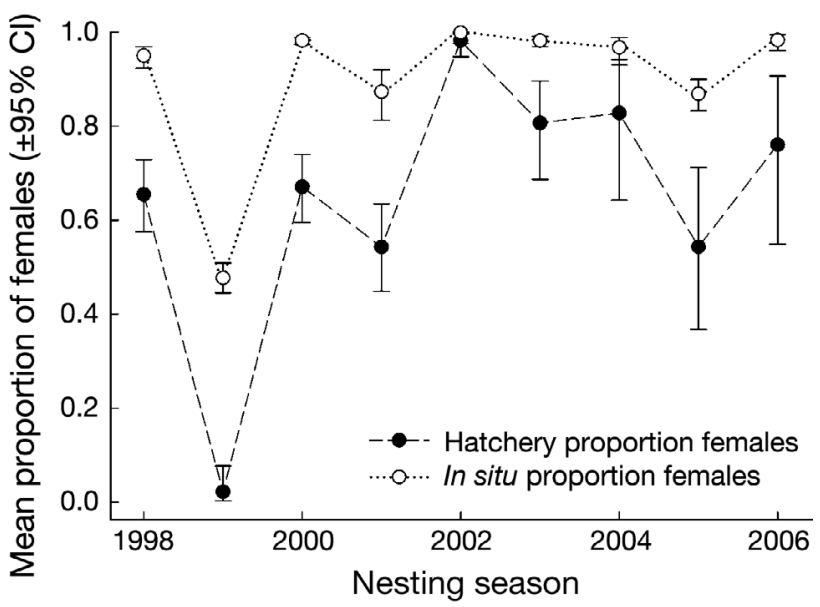

Fig. 1. Relocation to the hatchery decreased the female-bias of Playa Grande leatherback turtle sex ratios from 1998 to 2007. Error bars are binomial $95 \%$ confidence intervals (Clopper \& Pearson 1934)
Incubation temperatures in the hatchery followed the same trajectory of increase throughout the middle third of incubation as in in situ clutches. However, hatchery clutch temperatures were significantly lower than those in in situ clutches by ca. $0.7^{\circ} \mathrm{C}$ overall (Fig. 2). The reduced hatchery incubation temperatures occurred without any significant differences between hatchery and in situ sand temperature (Fig. 3), although there were significant differences in overall sand temperatures between nesting seasons (bootstrapped 2-way ANOVA, $F_{\text {boot }}=1.78\left[F_{\text {crit }}=\right.$ 1.56], $\mathrm{p}<0.001)$. The interaction term in this analysis was not significant.

Location $\left(F_{1,1174}=153.7, \mathrm{p}<0.001, \eta^{2}=0.12\right)$ and month $\left(F_{3,1174}=124.1, \mathrm{p}<0.001, \eta^{2}=0.24\right)$ had significant effects on middle-third incubation temperatures. Location $\left(F_{1,1174}=185.8, \mathrm{p}<0.001, \eta^{2}=0.14\right)$ and month $\left(F_{3,1174}=175.4, \mathrm{p}<0.001, \eta^{2}=0.31\right)$ also had significant effects on metabolic heating (Fig. 4). Middle-third incubation temperatures were greater in in situ clutches $(+0.022$, CI: 0.018 to $0.025, \mathrm{p}<0.001)$. Metabolic heating was also greater in in situ clutches $(+0.20, \mathrm{CI}: 0.17$ to $0.23, \mathrm{p}<0.001)$. Middle-third incubation temperatures progressively increased throughout the nesting season: December > October/ November $(+0.014, \mathrm{CI}: 0.009$ to $0.020, \mathrm{p}<0.001)$,

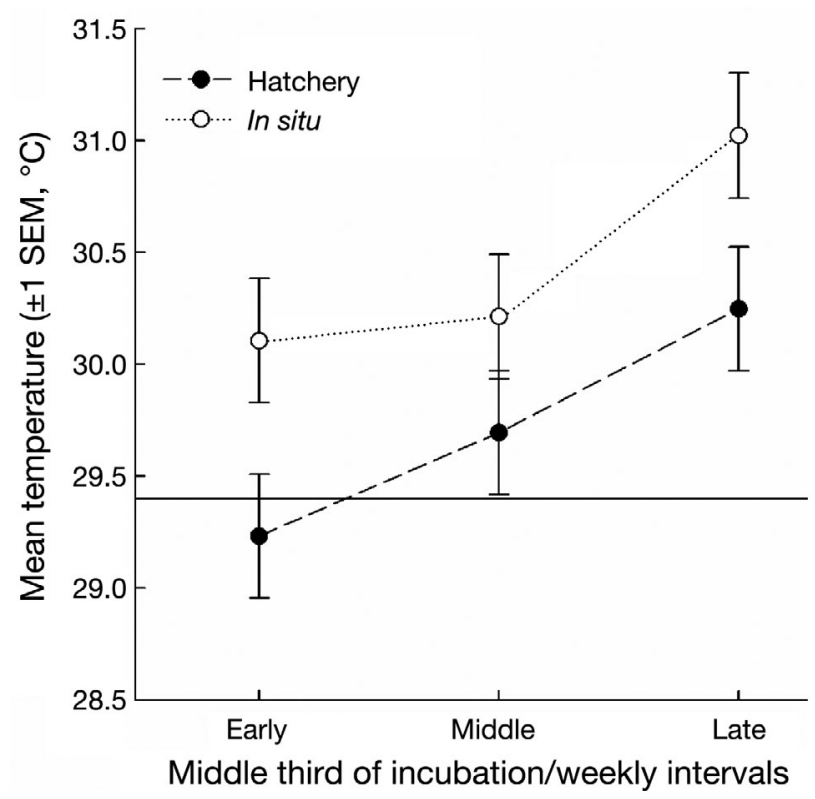

Fig. 2. The pattern of temperature increase during the middle third of incubation was consistently depressed in hatchery egg clutches of leatherback turtles. Mean temperatures for $1 \mathrm{wk}$ intervals within the middle third of incubation in hatchery and in in situ egg clutches were above the pivotal temperature (reference line $=29.4^{\circ} \mathrm{C}$ ) except in the earliest part of the middle third in the hatchery. Error bars are 1 standard error of the mean (SEM) 

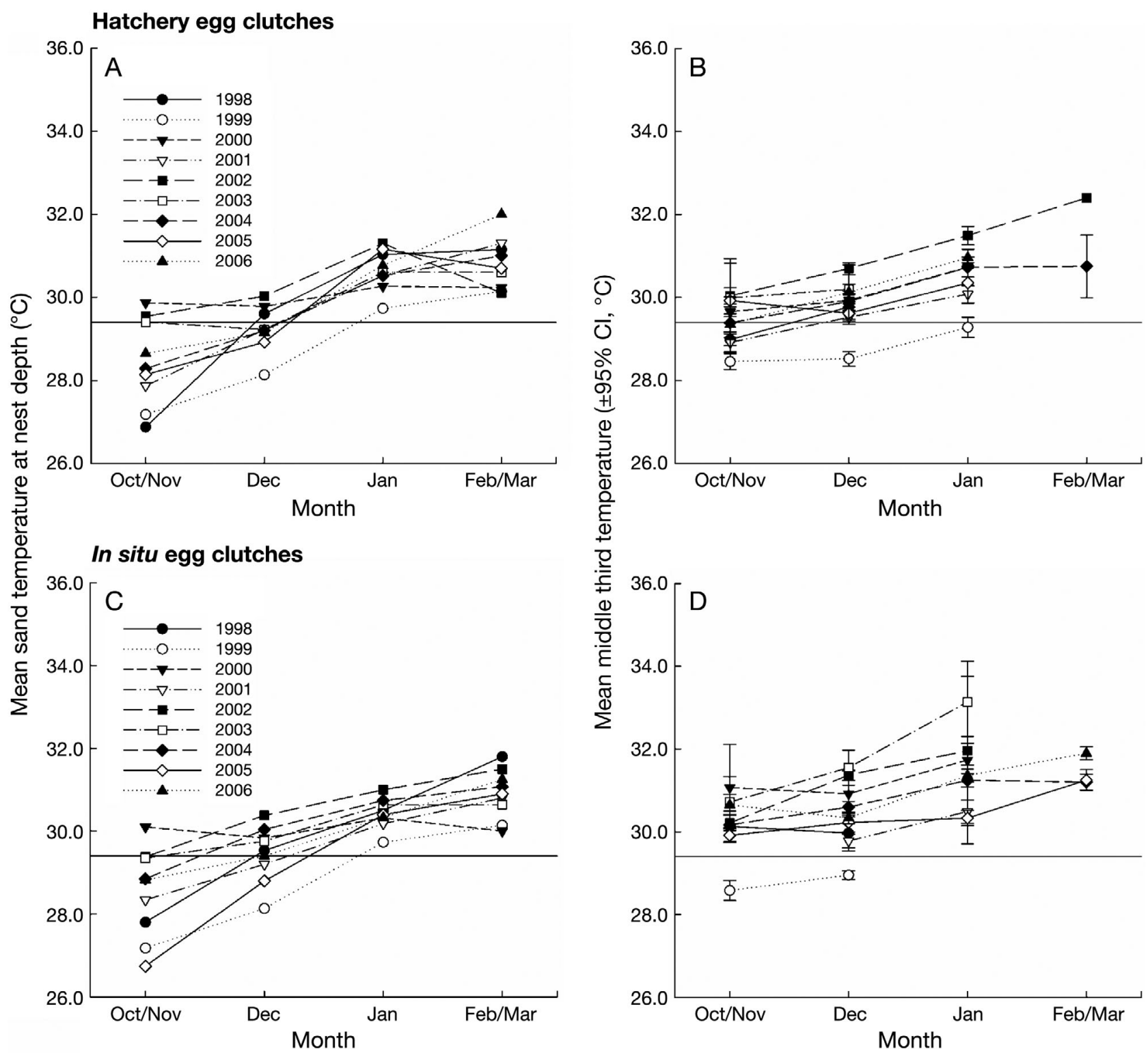

Fig. 3. In situ and hatchery egg clutch mean middle-third temperatures are both female biased in all years except 1999 to 2000. (A) Hatchery sand temperatures at nest depth are above the pivotal temperature (reference line $=29.4^{\circ} \mathrm{C}$ ) by January in all years and (B) hatchery egg clutch temperatures are above pivotal by December in every year except 1999 to 2000 . (C) In situ sand temperatures are also above pivotal by January in all years while (D) in situ egg clutch temperatures are above the pivotal temperature throughout each season except 1999 to 2000. Sand temperatures at nest depth do not have error bars because measurements were not spatially replicated. Egg clutch mean middle-third temperature error bars are $95 \%$ confidence intervals. Error bars are missing in months with $\mathrm{n}<5$, and data points are missing in months without in situ egg clutch temperature measurements

January $>$ December $(+0.019$, CI: 0.014 to $0.025, \mathrm{p}<$ $0.001)$, and February/March $>$ January $(+0.013, \mathrm{CI}$ : 0.006 to $0.019, \mathrm{p}<0.001)$. Conversely, metabolic heating progressively decreased during just the first half of the nesting season: December < October/November $(-0.21, \mathrm{CI}:-0.26$ to $-0.17, \mathrm{p}<0.001)$, January < December $(-0.16, \mathrm{CI}:-0.21$ to $-0.12, \mathrm{p}<0.001)$, and there were no significant differences between metabolic heating levels in January and February/March.

\section{DISCUSSION}

The overall female-biased sex ratios of $83.2 \%$ female observed at Playa Grande from 1998 to 2007 were consistent with earlier estimates from 1993 to 1996 of 74.3 to $100 \%$ female (Binckley et al. 1998). Estimates from the largest leatherback nesting colony in the Atlantic Ocean in Suriname were $69.4 \%$ female (Godfrey et al. 1996) and $60.5 \%$ 


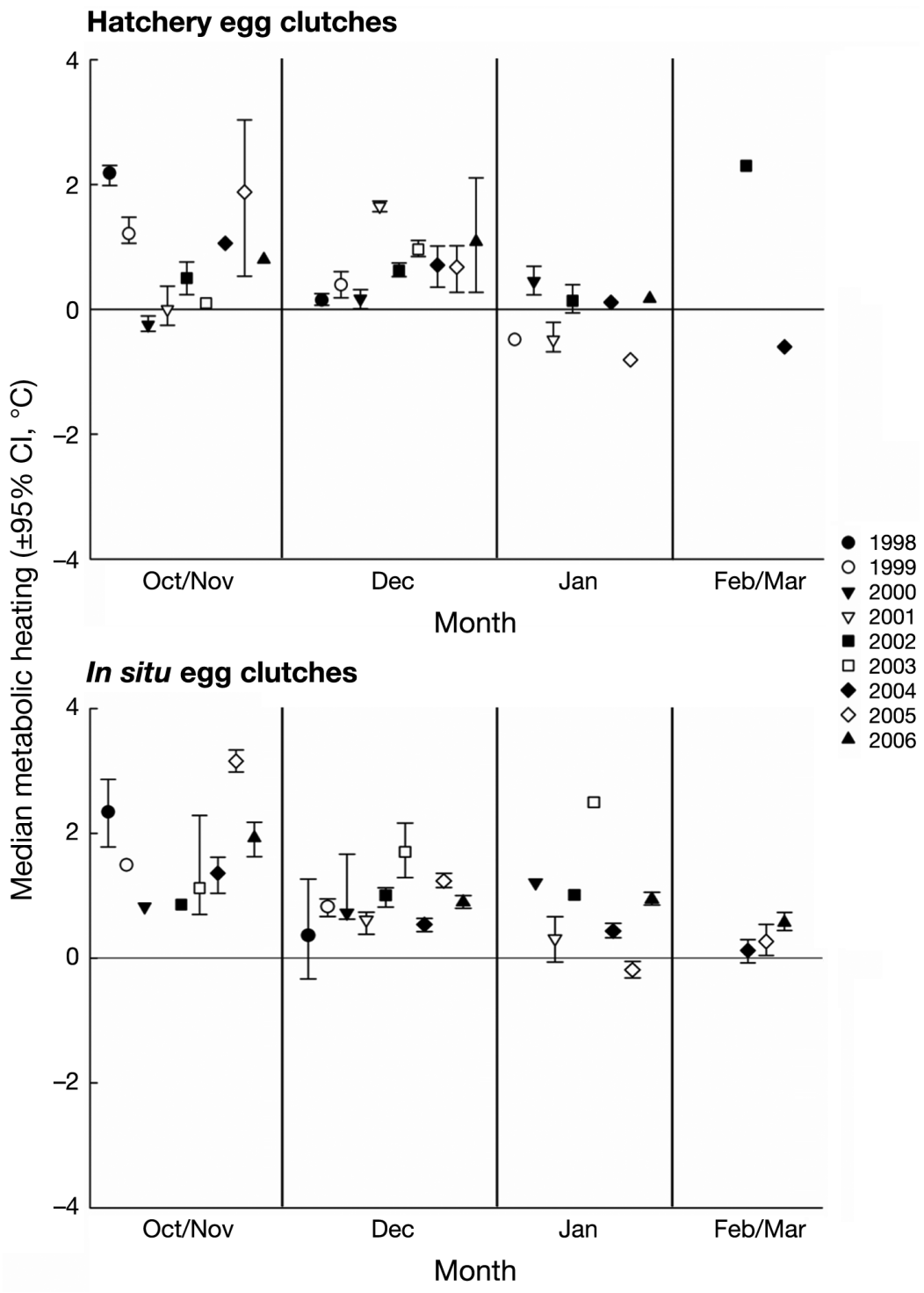

Fig. 4. Metabolic heating, which is calculated as the difference between the mean middle-third temperature (MMT) and the sand temperature at nest depth (STND), was generally less than $1^{\circ} \mathrm{C}$ in all leatherback turtle egg clutches during the middle third of development in (A) the hatchery and in (B) in situ egg clutches. The $95 \%$ confidence interval error bars are missing in months with $\mathrm{n}<5$, and data points are missing in months without in situ egg clutch temperature measurements

female (49.0 to $67.8 \%$; Mrosovsky et al. 1984), and estimates were often greater than $85 \%$ female for other sea turtle species (Mrosovsky \& Provancha 1992, Godfrey et al. 1999, Broderick et al. 2000, Wibbels 2007, Chu et al. 2008). At Playa Grande, in every season except 1999 to 2000, hatchery and in situ middle-third temperatures were both above the pivotal temperature from December through to the end of the nesting season. As hatching peaks in late December/early January, this corresponds to female-biased or completely female-producing incu- bation temperatures for the majority of nests. Tempering this female bias on Playa Grande was strong interannual variation in female bias (e.g. male bias in 1999 to 2000, Fig. 1), intra-annual variation in incubation temperatures with at least some males produced early in most nesting seasons (Fig. 3), and a decrease in incubation temperature associated with hatchery translocation (Fig. 2). Much of this variation was only observable because we were working with a long-term dataset of temperature measurements in both natural and hatchery clutches.

\section{Intra- and inter-seasonal variation}

Sex ratio estimates typically have not incorporated intra- or interseasonal differential mortality in egg clutches although it has long been recognized as an important effect (Godfrey \& Mrosovsky 1999, Matsuzawa et al. 2002). Intra-seasonally, if we incorporate monthly natural emergence success measured from 2004 to 2007 (Santidrián Tomillo et al. 2009) into the sex ratio estimated from incubation temperature measurements, the estimated number of female hatchlings produced in in situ egg clutches becomes 18132 (out of 21648 hatchlings) giving a sex ratio of $83.8 \%$ female hatchlings. Thus, our in situ female bias for 2004 to 2007 was overestimated by $4.5 \%$ when it did not include the mortality effect. However, this difference did not impact the overall conclusions of our analysis.

Seasonal differential mortality is related to changes in the thermal and hydric conditions surrounding incubating eggs (reviewed by Santidrián Tomillo et al. 2009), although seasonal beach dynamics related to tides (erosion, inundation) can also affect hatching and emergence success of clutches (e.g. Leslie et al. 1996). Coinciding with the nesting season at Playa Grande, there is a transition from the end of the rainy season in November into the dry season for the remainder of the nesting period during which little to no rain falls (Coen 1983). Greater hatching and emer- 
gence success, greater production of males, and increased metabolic heating are observed in earlyseason clutches and in rainier years (e.g. 1999 to 2000, 2005 to 2006; Santidrián Tomillo et al. 2009, authors' unpubl. data). Thus, when male production occurs at Playa Grande, it coincides with ambient thermal and hydric conditions that promote greater emergence success. It would be interesting to examine whether the predation environment for hatchlings differs with respect to seasonal progression or the biophysical environment.

\section{Sex ratios and conservation}

Reduced incubation temperatures in hatchery relative to in situ clutches could be related to a variety of external factors, but many of the important influences found on other beaches do not systematically apply on Playa Grande. The Playa Grande hatchery was not differentially shaded by nearby vegetation (Carrasco et al. 2000, Janzen 1994) as compared to the open beach, where the vast majority of nests are laid (Nordmoe et al. 2004). Sand in the hatchery was interchanged with beach sand regularly and there were no significant differences between sand temperatures in the hatchery versus the natural nesting beach. Consistent attempts are made to recreate natural nest dimensions and depths in hatchery nests (Wallace et al. 2004). Sand temperatures and incubation temperatures were more heterogeneous on the beach as compared to in the hatchery, and that resulted in the unexplained variation in our statistical models. However, influences such as proximity to the water table (the hatchery was well above the high tide line), and shading from dry forest vegetation bordering the beach (the hatchery was surrounded by low-profile ground cover vegetation) were likely to cool some in situ clutches relative to concurrent hatchery clutches.

The most parsimonious explanation for the effect of hatchery translocation is that lower numbers of metabolizing embryos per clutch in hatchery clutches decreased the metabolic heating contribution to incubation temperature and, thus, depressed incubation temperatures relative to those in in situ clutches. Preliminary results suggests that hatching success in hatchery clutches is approximately $10 \%$ less than in in situ clutches (2004 to 2007; P. Santidrián Tomillo et al. unpubl. data). This decrease in hatchery hatching success is similar to levels observed at the St. Croix leatherback turtle rookery (Eckert \& Eckert 1990, Boulon et al. 1996) and in
Mexico (García et al. 2003). Our observation of significantly decreased metabolic heating in hatchery clutches also supports this line of reasoning.

The effects of metabolic heating on clutch incubation temperatures have been investigated in many sea turtle species (reviewed by Zbinden et al. 2007). Metabolic heating is tied to clutch size (Broderick et al. 2001, Zbinden et al. 2007), position within the nest (e.g. center versus periphery; Hansen et al. 1998), and the number of live versus decomposing embryos in the egg clutch (Broderick et al. 2001). We observed decreases in metabolic heating with progression through the season and with incubation in the hatchery versus in situ. Both of these effects are likely tied to differential embryo mortality from early to late in the nesting season (Santidrián Tomillo et al. 2009) and with translocation to the hatchery (P. Santidrián Tomillo et al. unpubl. data). This is in contrast to previous studies that observed increased incubation temperatures in translocated nests with $20 \%$ decreased hatching success (Hoekert et al. 1998, Pintus et al. 2009). One explanation for these contradictory findings is that there was greater metabolic activity of the microorganisms associated with decomposition in the translocated clutches in studies with $\sim 20 \%$ decreased hatching success. Finally, these results re-emphasize the importance of metabolic heating to primary sex ratios (Broderick et al. 2001), an effect that may be overlooked because metabolic heating in the last third of development is several times that during the middle third.

There was only a $0.7^{\circ} \mathrm{C}$ difference in the middle third incubation temperatures between in situ nests and hatchery nests, yet that resulted in a difference of $25.3 \%$ in the sex ratio between the 2 types of nest. The reason for that great effect was that the temperature difference occurred right in the range of the transition between male to female in the temperature/sex determination curve (Binckley et al. 1998). Therefore, it is important to carefully measure temperatures inside clutches of eggs incubating in natural nests and in hatchery nests in order to accurately assess the sex ratio of hatchlings produced on a nesting beach. This will provide the data needed to accurately assess the effect of management techniques and to develop long term strategies for management of nesting beaches. Furthermore, we recommend that this approach be adopted for the beach relocation of egg clutches only relatively short distances, such as up above the high tide line, which will enable managers to assess hatching success and sex ratio outcomes for a variety of relocation techniques on their nesting beach (see Tuttle \& Rostal 2010). 


\section{Implications}

The Playa Grande beach hatchery, while boosting hatchling production overall, has consistently decreased the natural female bias. Hatchery translocation at Playa Grande has been minimal (9\%) compared to many other leatherback turtle nesting beaches: an average of $43 \%$ in St. Croix, US Virgin Islands (Dutton et al. 2005); $80 \%$ in Pacific Mexico (Sarti Martínez et al. 2007); 16.7 \% in Espíritu Santo, Brazil (Thomé et al. 2007); and up to $53 \%$ in Terengganu, Malaysia (Mortimer 1989). For Playa Grande, a dynamic beach subject to erosion and dramatic seasonal changes in tidal height, translocation of clutches laid below the high tide line is warranted because hatching success would likely otherwise be zero and changes to the overall sex ratio on the beach are minimal. However, widespread clutch relocation would not be justifiable, in the absence of a strong threat such as rampant egg harvest (Mortimer 1999). As alterations of sex ratios, as well as of hatching and emergence success may occur with egg clutch translocation, we recommend that use of this technique be avoided whenever possible in favor of protection of egg clutches in their natural sites where imminent threats to embryonic survival are absent.

\section{CONCLUSIONS}

Playa Grande, like many other sea turtle nesting beaches, is generally female biased ( $83 \%$ female). Our long-term monitoring further revealed that occasional years of male-biased incubation occurred (1999 to 2000) and that translocation of doomed-eggs to the beach hatchery lessened female bias of those eggs, probably by decreasing the number of metabolizing embryos. With this knowledge of natural trends in leatherback primary sex ratios, managers can more accurately assess population growth rates and the use of doomed-egg translocation in their evaluation of appropriate conservation efforts in response to future anthropogenic threats. However, until it is clear that there is actually a need to produce more males or females in a sea turtle population in response to global warming or other human induced environmental changes it would be a bad idea to manipulate sex ratios of hatchlings via artificial incubation in a hatchery or other facility. It would be better to allow sea turtles to nest on natural beaches that migrate and adjust their characteristics in response to changing sea levels than to invest in artificial means to change sex ratios.
Acknowledgements. We thank L. Stokes, V. Saba, G. Blanco, and numerous other field assistants and volunteers for their contributions to the dataset. R. Piedra, MINAET park guards and local guides, C. Padilla, M. Boza, and E. Chacón are invaluable facilitators of research and conservation at Playa Grande. M. O'Connor and J. Suss kindly assisted with analyses. We acknowledge financial support from the Earthwatch Institute, the Betz Chair of Environmental Science at Drexel University, the Schrey Chair of Biology at Purdue University, The Leatherback Trust, the Goldring Family Foundation and the Panaphil Foundation. Research was conducted under permits by the Drexel University animal care committee and the Costa Rican Ministry of the Environment.

\section{LITERATURE CITED}

Binckley CA, Spotila JR, Wilson KS, Paladino FV (1998) Sex determination and sex ratios of Pacific leatherback turtles, Dermochelys coriacea. Copeia 1998:291-300

Boulon RH Jr., Dutton PH, McDonald DL (1996) Leatherback turtles (Dermochelys coriacea) on St. Croix, U.S. Virgin Islands: fifteen years of conservation. Chelonian Conserv Biol 2:141-147

Broderick AC, Godley BJ, Reece S, Hays GC (2000) Incubation periods and sex ratios of green turtles: highly female biased hatchling production in the eastern Mediterranean. Mar Ecol Prog Ser 202:273-281

Broderick AC, Godley BJ, Hays GC (2001) Metabolic heating and the prediction of sex ratios for green turtles (Chelonia mydas). Physiol Biochem Zool 74:161-170

> Bull JJ (1980) Sex determination in reptiles. Q Rev Biol 55: $3-21$

Bustard HR (1972) Sea turtles, their natural history and conservation. Collins, London

Carrasco MA, Márquez R, Díaz J, Benitez V, Villanueva N, Jiménez MC (2000) Effect of partial shadow in the incubation temperature in Kemp's ridley (Lepidochelys kempii) nest, in the beach hatcheries, at Rancho Nuevo, Tamaulipas, Mexico. In: Abreu-Grobois FA, BriseñoDueñas R, Márquez R, Sarti L (comps), Proc 18th Int Sea Turtle Symp. U.S. Department of Commerce. NOAA Technical Memo. NMFS-SEFSC-436, National Marine Fisheries Service, Miami, FL, p 43-44

Chan EH, Liew HC (1995) Incubation temperatures and sexratios in the Malaysian leatherback turtle Dermochelys coriacea. Biol Conserv 74:169-174

Chu CT, Booth DT, Limpus CJ (2008) Estimating the sex ratio of loggerhead turtle hatchlings at Mon Repos rookery (Australia) from nest temperatures. Aust J Zool 56: $57-64$

> Clopper CJ, Pearson ES (1934) The use of confidence or fiducial limits illustrated in the case of the binomial. Biometrika 26:404-413

Coen E (1983) Climate. In: Janzen DH (ed) Costa Rica natural history. University of Chicago Press, Chicago, IL, p 35-46

Dutton DL, Dutton PH, Chaloupka M, Boulon RH (2005) Increase of a Caribbean leatherback turtle Dermochelys coriacea nesting population linked to long-term nest protection. Biol Conserv 126:186-194

$>$ Eckert KL, Eckert SA (1990) Embryo mortality and hatch success in in situ and translocated leatherback sea turtle Dermochelys coriacea eggs. Biol Conserv 53:37-46 
Ewen JG, Clarke RH, Moysey E, Boulton RL, Crozier RH, Clarke MF (2001) Primary sex ratio bias in an endangered cooperatively breeding bird, the black-eared miner, and its implications for conservation. Biol Conserv 101:137-145

García A, Ceballos G, Adaya R (2003) Intensive beach management as an improved sea turtle conservation strategy in Mexico. Biol Conserv 111:253-261

Godfrey M, Mrosovsky N (1999) Estimating hatchling sex ratios. In: Eckert KL, Bjorndal KA, Abreu-Grobois, FA, Donnelly M (eds), Research and management techniques for the conservation of sea turtles. IUCN/ SSC Marine Turtle Specialist Group Publication No. 4, Consolidated Graphic Communication, Blanchard, PA, p 136-138

Godfrey MH, Barreto R, Mrosovsky N (1996) Estimating past and present sex ratios of sea turtles in Suriname. Can J Zool 74:267-277

Godfrey MH, D'Amato AF, Marcovaldi MA, Mrosovsky N (1999) Pivotal temperature and predicted sex ratios for hatchling hawksbill turtles from Brazil. Can J Zool 77: 1465-1473

Hanson J, Wibbels T, Martin RE (1998) Predicted female bias in sex ratios of hatchling loggerhead sea turtles from a Florida nesting beach. Can J Zool 76:1850-1861

Hays GC, Ashworth JS, Barnsley MJ, Broderick AC and others (2001) The importance of sand albedo for the thermal conditions on sea turtle nesting beaches. Oikos 93:87-94

Hays GC, Broderick AC, Glen F, Godley BJ (2003) Climate change and sea turtles: a 150-year reconstruction of incubation temperatures at a major marine turtle rookery. Glob Change Biol 9:642-646

Hilton-Taylor C (comp) (2000) IUCN Red List of threatened species. IUCN, Gland

Hoekert WEJ, van Tienen LHG, van Nugteren P, Dench S (1998) The 'sea turtles of Suriname 1997'—project comparing relocated nests to undisturbed nests. In: AbreuGrobois FA, Briseño-Dueñas R, Márquez R, Sarti L (comps) Proc 18th Int Sea Turtle Symp. U.S. Department of Commerce. NOAA Technical Memo. NMFS-SEFSC436, National Marine Fisheries Service, Miami, FL, p 192-193

Janzen FJ (1994) Vegetational cover predicts the sex ratio of hatchling turtles in natural nests. Ecology 75 : 1593-1599

Leslie AJ, Penick DN, Spotila JR, Paladino FV (1996) Leatherback turtle, Dermochelys coriacea, nesting and nest success at Tortuguero, Costa Rica, in 1990-1991. Chelonian Conserv Biol 2:159-168

Matsuzawa Y, Sato K, Sakamoto W, Bjorndal KA (2002) Seasonal fluctuations in sand temperature: effects on the incubation period and mortality of loggerhead sea turtle (Caretta caretta) pre-emergent hatchlings in Minabe, Japan. Mar Biol 140:639-646

Morreale SJ, Ruiz GJ, Spotila JR, Standora EA (1982) Temperature-dependent sex determination: current practices threaten conservation of sea turtles. Science 216: 1245-1247

Mortimer JA (1989) Threats to the survival of Terengganu's sea turtles and a review of management options. WWF Project 3868 Report, WWF Malaysia, Petaling Jaya, Selangor

Mortimer JA (1999) Reducing threats to eggs and hatchlings: hatcheries. In: Eckert KL, Bjorndal KA, AbreuGrobois FA, Donnelly M (eds) Research and manage- ment techniques for the conservation of sea turtles. IUCN/SSC Marine Turtle Specialist Group Publication No. 4, National Marine Fisheries Service, Miami, FL, p 175-178

- Mrosovsky N (2006) Distorting gene pools by conservation: assessing the case of doomed turtle eggs. Environ Manag 38:523-531

Mrosovsky N (2008) Against oversimplifying the issues on relocating turtle eggs. Environ Manag 41:465-467

> Mrosovsky N, Provancha J (1992) Sex ratio of hatchling loggerhead sea turtles: data and estimates from a 5-year study. Can J Zool 70:530-538

Mrosovsky N, Hopkins-Murphy SR, Richardson JI (1984) Sex ratio of sea turtles: seasonal changes. Science 225: 739-741

Mrosovsky N, Kamel SJ, Diez CE, van Dam RP (2009) Methods of estimating natural sex ratios of sea turtles from incubation temperatures and laboratory data. Endang Species Res 8:147-155

Nordmoe ED, Sieg AE, Sotherland PR, Spotila JR, Paladino FV, Reina RD (2004) Nest site fidelity of leatherback turtles at Playa Grande, Costa Rica. Anim Behav 68: 387-394

Pfaller JB, Limpus CJ, Bjorndal KA (2009) Nest-site selection in individual loggerhead turtles and consequences for doomed-egg relocation. Conserv Biol 23:72-80

Pike DA (2008) The benefits of nest relocation extend far beyond recruitment: a rejoinder to Mrosovsky. Environ Manag 41:461-464

Pintus KJ, Godley BJ, McGowan A, Broderick AC (2009) Impact of clutch relocation on green turtle offspring. $\mathrm{J}$ Wildl Manag 73:1151-1157

Reina RD, Mayor PA, Spotila JR, Piedra R, Paladino FV (2002) Nesting ecology of the leatherback turtle, Dermochelys coriacea, at Parque Nacional Marino Las Baulas, Costa Rica: 1988-1989 to 1999-2000. Copeia 2002:653-664

> Santidrián Tomillo P, Vélez E, Reina RD, Piedra R, Paladino FV, Spotila JR (2007) Reassessment of the leatherback turtle (Dermochelys coriacea) nesting population at Parque Nacional Marino Las Baulas, Costa Rica: effects of conservation efforts. Chelonian Conserv Biol 6:54-62

Santidrián Tomillo P, Suss JS, Wallace BP, Magrini KD, Blanco G, Paladino FV, Spotila JR (2009) Influence of emergence success on the annual reproductive output of leatherback turtles. Mar Biol 156:2021-2031

> Sarti Martínez L, Barragán AR, García Muñoz D, García N, Huerta P, Vargas F (2007) Conservation and biology of the leatherback turtle in the Mexican Pacific. Chelonian Conserv Biol 6:70-78

Standora EA, Spotila JR (1985) Temperature dependent sex determination in sea turtles. Copeia 1985:711-722

Steyermark AC, Williams K, Spotila JR, Paladino FV and others (1996) Nesting leatherback turtles at Las Baulas National Park, Costa Rica. Chelonian Conserv Biol 2: 173-183

> Thomé JCA, Baptistotte C, Moreira LM de P, Scalfoni JT, Almeida AP, Rieth DB, Barata PCR (2007) Nesting biology and conservation of the leatherback sea turtle (Dermochelys coriacea) in the state of Espíritu Santo, Brazil, 1988-1989 to 2003-2004. Chelonian Conserv Biol 6: $15-27$

Tuttle J, Rostal D (2010) Effects of nest relocation on nest temperature and embryonic development of loggerhead 
sea turtles (Caretta caretta). Chelonian Conserv Biol 9: $1-7$

van de Merwe J, Ibrahim K, Whittier J (2006) Effects of nest depth, shading, and metabolic heating on nest temperatures in sea turtle hatcheries. Chelonian Conserv Biol 5: 210-215

Wallace BP, Sotherland PR, Spotila JR, Reina RD, Franks BF, Paladino FV (2004) Biotic and abiotic factors affect the nest environment of embryonic leatherback turtles, Dermochelys coriacea. Physiol Biochem Zool 77: 423-432

Editorial responsibility: Mathew Godfrey, Beaufort, North Carolina, USA
Wibbels T (2007) Sex determination and sex ratios in ridley turtles. In: Plotkin PT (ed) Biology and conservation of ridley sea turtles. Johns Hopkins University Press, Baltimore, MD, p 167-189

Wilson DS (1998) Nest-site selection: microhabitat variation and its effects on the survival of turtle embryos. Ecology 79:1884-1892

Zbinden JA, Davy C, Margaritoulis D, Arlettaz R (2007) Large spatial variation and female bias in the estimated sex ratio of loggerhead sea turtle hatchlings of a Mediterranean rookery. Endang Species Res 3:305-312

Submitted: January 19, 2011; Accepted: July 27, 2011 Proofs received from author(s): November 9, 2011 